Jurnal Indonesia Sosial Teknologi: p-ISSN: 2723 - 6609

e-ISSN : 2745-5254

Vol. 2, No. 11 November 2021

\title{
PEMBUKTIAN TERBALIK DALAM TINDAK PIDANA KORUPSI
}

\author{
Hari Soeskandi $^{1}$, Setia Sekarwati ${ }^{2}$ \\ Universitas 17 agustus 1945 Surabaya $^{1,2}$ \\ Email: hari.soeskandi@gmail.com ${ }^{1}$, setiasekarwati13@gmail.com ${ }^{2}$
}

\begin{abstract}
Abstrak
Kajian ini dilaksanakan agar bisa mencari tahu upaya pembuktian atas beban pembuktian terbalik pada tindak pidana korupsi. Kajian ini tergolong sebagai kajian hukum normatif. Dilakukan menggunakan pendekatan undang-undang, serta konseptual.Bahan hukum primer berwujud undang-undang terkumpulkan mempergunakanprosedur inventarisasi maupun kategorisasi.Bahan hukum yang didapat setelah dihimpun dan disusun, kemudian dianalisa serta diidentifikasi dengan mempergunakan teknik analisis prespkriptif melalui metode sistematisasi. Sehingga dapat ditarik kesimpulan dan memberikan saran sesuai dengan permasalahannya. Dalam pembuktian terbalik, yang wajib melakukan pembuktian ialah terdakwa. Sesudah terdakwa mendapatkan perintah dari hakim selama memeriksa persidangan pengadilan. Walau Perundang- Undangan No. 8 Tahun 2010 perihal Pemberantasan Tindak Pidana Pencucian Uang tanpa memperjelas perihal waktu terbaik untuk terdakwa membukatikan hartanya, tetapi bila mencermati sistematika pengadilan. Oleh sebab itulah, saat pemeriksaan atau mendengar keterangan terdakwa itulah saat yang tepat untuk melakukan proses pembuktian. Tahap membuktikan tindakan yang dilaksanakan terdakwa memiliki tujuan guna menjelaskan asal muasal harta kekayaan, diikuti oleh bukti yang memperjelas waktu, asal, dan upaya mendapatkan harta kekayaan.
\end{abstract}

Kata kunci: tindak pidana; korupsi; pembuktian terbalik.

\section{Abstract}

This study was carried out in order to find out the efforts to prove the reverse burden of proof in corruption crimes. This study is classified as a normative legal study. It is carried out using a statutory and conceptual approach. Primary legal materials in the form of laws are collected using an inventory and categorization procedure. Legal materials obtained after being compiled and compiled are then analyzed and identified using prescriptive analysis techniques through the systematization method. So that conclusions can be drawn and provide suggestions according to the problem. In reverse proof, it is the defendant who is obliged to prove it. After the defendant received an order from the judge during the examination of the court trial. Although Law No. 8 of 2010 concerning the Eradication of the Crime of Money Laundering without clarifying the best time for the defendant to reveal his assets, but if you look at the court systematization. Therefore, when examining or hearing the testimony of the defendant, it is the right time to carry out the proof process. The stage of proving the actions carried out by the defendant has the aim of explaining the origin of the 
assets, followed by evidence that clarifies the time, origin, and efforts to obtain the assets.

Keywords: criminal act; corruption; reverse proof.

\section{Pendahuluan}

Indonesia ialah negara hukum, sebab mempunyai peraturan hukum berupa undang-undang. Perihal itu diperjelas melalui Pasal 1 Ayat (3) UUD 1945. Asas ini memiliki arti bila di Indonesia, hukum ialah faktor penentu bagi segala aspek kehidupan. Hukum berposisi secara terstruktur dan mendominasi di segala kehidupan masyarakat. Secara inti, negara hukum hukum atau tindakan pemerintah ataupun rakyat berdasar hukum guna melakukan pencegahan atas tindakan kesewenangan pemerintah (penguasa) dan tindakan rakyat yang dilaksanakan atas keinginan sendiri.

Dalam suatu negara hukum, pemerintah harus memberi jaminan bila terdapat upaya menegakkan hukum dan pencapaian hukum. Dalam buku Sudikno Mertokususumo dan Pitlo yang berjudul bab-bab penemuan hukum telah dijelaskan bila upaya menegakkan hukum ada tiga unsur yang perlu memperoleh simpati, meliputi kebermanfaatan (doelmatigheid), keadilan, dan kepastian hukum (Mertokusumo \& Pitlo, 1993). Tujuan utama hukum ialah penciptaanatas tata tertib. Hukum perlu terlaksana dan perlu ditegakkan; fiat justitia et pereat mundus (meski dunia ini mengalami keruntuhan, hukum tetap ditegakkan). Tiap individu yang berharap bisa ditentukannya hukum bila ada suatu kejadian. Hal tersebut sebagai pemahaman dari kepastian hukum. Kepastian hukum ialah perlindungan justiciable dari tindakan berkesewenang-wenangan, yang menjelaskan bila seseorang hendak memperoleh sesuatu yang diinginkan berkeadaan tertentu. Masyarakat memiliki harapan ada kepastian, sehingga melalui kepastian hukum ini, masyarakat bisa menaati ketertiban.

Hukum berperan menghasilkan kepastian hukum, serta kepastian hukum bisa memberi peluang guna pencapaian tujuan hukum lainnya, yakni tata tertib masyarakat (Budiartha, 2016). Dalam menegakkan hukum di satu sisin perlu terdapat kepastian hukum yang diupayakan perlu memberikan manfaat bagi masyarajat, tidak hanya menciptakan keadilan. Dalam menegakkan hukum perlu dilaksanakan supaya ada suatu peraturan hukum guna melindungi kepentingan antarmanusia, sudah terlanggar, dan dicegah melalui kehadiran hukum pidana.

Melanggar hukum atau peraturan yang sudah ditentukan disebut sebagai tindak pidana. Seperti yang kerap disebut padaKUHP, yaitu sebagai fundamental dari semua sistem hukum pidana Indonesia pada suatu undang-undang pidana sebagai keseluruhan (Lamintang, 1997). Akan tetapi, terdapat bermacam ahli yang menggunakan delik sebagai laih bahasa daristrafbaarfeit. Tindak pidana pada KUHP terbagi atas dua macam, yakni kejahatan dan pelanggaran.

Kejahatan merupakan gejala normal pada tiap masyarakat, bagaimana bentuk masyarakat tersebut, di mana maupun kapan saja (Runturambi, 2017). Begitupun dengan apa yang ada di Indonesia sekarang, sehingga rumitnya masalah bangsa dan negara yang 
tengah dialami, mulai dari krisis ekonomi berkepanjangan,sampai memengaruhi adanya krisis politik, kepercayaan kepada pemerintah, sampai adanya krisis hukum, memicu angka kejahatan mengalami peningkatan dengan tajam. Tidak hanya itu, tidak bisa dipungkiri bila akibat dariglobalisasi sekarang ini ialah kemajuan ilmu pengetahuan, modernisasi, dan industrialisasi pun sudah memberikan perkembangan atas tindak kejahatan.

Akibat buruk dari globalisasi itu diakibatkan adanya pengabaian pada nilai norma, modal, etika, hak asasi manusia, maupun agama (Lalo, 2018). Meski negara barat tolok ukurnya berlainan dengan negara timur, termasuk Indonesia. Masyarakat harus kian mengoptimalkan mutunya agar bisa bertahan hidup. Namun, tututan pengoptimalan mutu hidup itu tanpa disertai oleh kapabilitas pemerintah menyediakan fasilitas guna memenuhi kebutuhan hidup. Dengan demikian, ada banyak masyarakat yang berupaya melakukan beragam tindakan guna mencukupi kebutuhan hidup mereka, termasuk bertindak pidana.

Kehidupan masyarakat sekarang ini berkembang cukup signifikan, dan memunculkan bermacam kasus tindak pidana yang meresahkan masyarakat. Modus tindakan pidana juga bermacam, seperti tindak pidana ringan: mencuri ayam hingga tindak pidana berat, misalnya perampokan, penggelapan, korupsi, maupun pembunuhan. Banyaknya tindak kejahatan, pasti mengakibatkan kondisi di dalam masyarakat tidak kondusif. Dengan demikian, aparat harus memberi tindakan tegas bagi pihak yang melanggar hukum berdasar pada aturan yang berlaku.

Pemberian sanksi itu memiliki maksud sebagai efek jera untuk pihak yang bertindak pidana, sehingga tidak mengulangi tindakan itu.

Korupsi di Indonesia sudah kerap dilakukan sejak zaman kerajaan, seperti ada keinginan raja yang harus terlaksanakan melalui penarikan upeti sesuka hati, dan berlanjut ke masa penjajahan, terutama pada masa pemerintahan VOC.Bermula dari janji manis guna menyejahterakan masyarakat, secara perlahan tindakan yang dilakukan VOC mengarah ke kerja paksa. Sama seperti masa kerajaan, pada masa VOC tindakan korupsi pun terkesan kontras melalui adanya penjarahan sumber daya alam yang sepatutnya diberikan bagi masyarakat asli, pemberian pajak atas kesewenangan, merampas harta, penyelewengan uang kas, dan lain-lain. Tindakan tersebut pun menjadi benih korupsi modern di Indonesia.

Sebelum reformasi, ketika konstitusi sebagai instrumen guna mempermudah kekuasaan bukan menjadi kontrol kekuasaan (Indrayana, 2011). Kebebasan pers pada periode tersebut seolah-oleh terbatasi oleh dinding yang dikenal sebagai kekuasaan otoriter, sehingga kekuasaan itu kian meluas tanpa ada pengontrolan melalui keterbukaan. Tidak hanya itu, kondisi seperti itu menjadi kesempatan bagi bagi angkatan bersenjata Indonesia guna mendominasi pemerintah, khususnya di bidang sosial-politik atau Dwifungsi ABRI. Atas dasar itu, terbukalah ruang yang memberi kesempatan bagi politisi elit guna mengekspoitasi negara, sehingga menciptakan sistem tata negara yang koruptif. Pada masa itu, korupsi bisa disebut sebagai tindakan yang terorganisasi dan terstruktur, 
sebab tanpa ada kasus korupsi yang terungkap, berbeda dengan saat ini yang memberitakan segala tindakan korupsi secara terang-terangan. Bahkan, pada periode itu belum terdapat peraturan yang mengatur tindakan korupsi. Saat itu, tindakan korupsi terlaksana secara rapi dan terkesan ditutup-tutupi berkat ada pembangunan yang terusterusan, bahkan melalui pemberian kesejahteraan untuk masyarakat.

Sekarang ini, korupsi terlaksana dengan bermacam modus yang berimbas langsung pada kehidupan berbangsa di Indonesia, serta dikhawatirkan bisa membahayakan stabilitas, keamanan, dan turut berimbas ke warga negaranya. Tidak hanya itu, tindak pidana korupsi pun turut mengarah ke bermacam aspek perekonomian, kebudayaan, ataupun sosial. Selama era demokrasi, khususnya melalui pemilu yang terlaksana secara jujur, berkeadilan, langsung, rahasia, bebas, dan umum bisa menjadi pesta rakyat yang menentukan siapa pemimpin atau sebagai penyambung lidah mereka. Pemilihan pejabat negara harus berlandaskan pada diri pejabat itu, seperti kebijakasnaan, arif, bermoral, dan tidak sekadar mencari kuasa semata (Supusepa, 2019).

Para penegak hukum khususnya Jaksa serta KPK harus bekerja secarea maksimal untuk memberi efek jera bagi para koruptor (Husodo et al., 2011). Pembuktian merupakan hal yang memegang peranan penting di persidangan selama menegakkan tindak pidana korupsi. Saat pemeriksaan di persidangan akan mengungkap fakta yang menetapkan apakah seseorang selaku terdakwa terbukti melakukan korupsi ataukah tidak. Upaya untuk membuktikan seseorang bertindak pidana korupsi ataukah tidak bisa diberlakukannya pembuktian terbalik. Prinsip pembuktian pembalikan beban ialah sistematika yang ada di luar kewajaran dalam membuktikanhukum acara pidana yang umum. Baik itu sistem kontinental ataupun Anglo Saxon yang mengenali pembuktian secara tetap memberi beban pada kewajiban pembuktian kepada jaksa penuntut umum.

Namun, pada kasus tertentu terdapat implementasi bermekanisme difrensial, yakni sistem membalikkan beban pembuktian dan itupun tidak dilakukan sepenuhnya serta masih memiliki batasan yang seminimal mungkin tidak melakukan pelanggaaran hukum yang berpeluang seperti hakprinsip korban, tersangka/terdakwa, masyarakat serta negara (Nurhayani, 2015). Beban pembuktian yang ada di Jaksa Penuntut Umum berkaitan pada asas praduga tidak bersalah (presumption of innocent) serta asas tidak sebagai eksplanasi dari prinsip umum hukum pidana: siapa yang melakukan penututan, berarti dirinyalah yang perlu memberi bukti kebenaran atas tuntutan mempermasalahkan diri sendiri (non- self incrimination). Dalam membebankan pembuktian terbalik, (Prasetia, Permana, \& Dewi, 2014) beban pembuktian yang disampaikanjaksa penuntut umum terlaksana secara universal bagi segala bentuk tindak pidana, termasik di dalam maupun di luar kodifikasi KUHP. Akan tetapi ada pengkhususan ke tindak pidana, khususnya yang ada di luar KUHP, seperti halnya korupsi yang tercantum di Perundang-Undangan No.31

Tahun 1999 jo Perundang-Undangan No. 20 Tahun 2001 terkait pemberantasan tindak pidana korupsi.

Pada perundang-undangan ada ketetapan mengenali pelaksanaan pembuktian terbalik yang awalnya diberikan ke jaksa penutut umum, kemudian diberikan kepada Jurnal Indonesia Sosial Teknologi, Vol. 2, No. 11, November 2021 
terdakwa. Bila tanpa bisa memberi bukti, terdakwa akan dianggap bersalah. Ketetapan ini termuat di Pasal 12 B Ayat (1) Huruf a dan b, Pasal 37, 37 A dan 38 B. Pada uraian yang terdapat di Pasal 37 Perundang-Undangan Nomor 31 Tahun 1999 menjelaskan bila ketetapan ini sebagai penyimpangan dari ketetapan KUHP, memberi ketetapan bila jaksa berkewajiban memberi bukti tindak pidana, dan bukanlah terdakwa. Sesuai ketetapan ini, terdakwa bisa memberi bukti bila dirinya tanpa bertindak pidana korupsi. Jika terdakwa bisa memberi bukti tanpa bertindak korupsi, berarti penutut umum tetap wajib memberi bukti dakwaannya (Barama, 2012). Ketetapan pada pasal ini sebagai upaya membuktikan secara terbalik yang terbatas, sebab jaksa mempunyai bukti guna membuktikan dakwaan.

Ketetapan terkait pembalikan beban pembuktian atau sistem pembalikan beban pembuktian (reversal of burden proof atau omkering van bewijslast) sebagai hasil pengadopsian sistem hukum Anglo Saxon/ negara yang menganutcase-law yang terbatas di kasus tertentu (certain cases), terutama tindak pidana terkait gratifikasi (gratification) atau menyuap (bribery). Pembuktian terbalikialah sistematika guna membuktikan sesuatu yang ada di luar prevalensi teoretis pembuktian pada hukum acara pidana yang umum.

\section{Metode Penelitian}

Jenis penelitian pada kajian hukum ialah hukum normatif maupun kajian hukum empiris. Dalam kajian hukum ini jenis penilitian yang digunakan ialah kajian hukum normatif yang bermaksud agar bisa memperoleh peraturan hukum, prinsip, ataupun doktrin hukum untuk memberi jawaban atas wacana hukum yang sedang dihadapi. Kajian hukum normatif terlaksana agar bisa memperoleh prosedur menyelesaikan permasalahan terkait isu hukum (legal issue) (Ryana \& Idzati, 2018). Hasil kajian ini, yaitu mendeskripsikan rumusan permasalahan yang terajukan. Kajian hukum normatif sekadar menganalisis norma hukum tanpa mencermati praktik hukum di lapangan (law in action).

\section{Pendekatan}

Keterkaitan dengan kajian normatif, pendekatan yang dipergunakan pada penulisan hukumsesuai penuturan Peter Mahmud Marzuki yaitu:

a. Pendekatan Undang-Undang

Terlaksana melalui penelaahan keseluruhan perundang-undangan dan aturan terkait isu hukum yang tengah ditangani. Melalui pendekatan undang-undang pada kajian normatif, maka bisa bermanfaat secara praktis ataupun akademis. Hasil penelaahan itu sebagai hipotesis atau argumentasi guna menyelesaikan isu hukum. Pendekatan aturan hukum undang-undang (statute aprroach) dipergunakan sebab hendak mengeliti peraturan hukum terkait kajian ini. Pendekatan ini diperlukan agar bisa memperoleh jawaban terkait materi muatan hukum yang terumuskan pada kajian ini.

\section{b. Pendekatan Konseptual}


Berawal dari perspektif, berkembangnya doktrin di ilmu hukum dengan mempelajari permasalahan-permasalahan dalam ilmu hukum, peneliti hendak memperoleh gagasan yang menciptakan definisi hukum, dan asas hukum sesuai wacana yang berkembang yang sedang dihadapi terkait pemahaman atas perspektif maupun doktrin itu sebagai dasar bagi peneliti selama merancang argumen hukum selama menyelesaikan wacana yang sedang dihadapi (Marzuki, 2011).

Pada kajian ini mempergunakan pendekatan undnag-undang dengan mengkaji suatu peraturan- perundangan yang sesuai dengan pokok pembahasan dalam rangka menemukan ketentuan hukum yang dapat dipakai sebagai landasan dalam penyusunan karya ilmiah ini.Pendekatan konseptual ialah pendekatan kajian yang bertolak ukur kepada perspektif ataupun doktrin yang mengalami perkembangan pada ilmu hukum dengan mencermati atau menggali pandangan dan doktrin itu bisa memperoleh definisi hukum maupun konsep hukum terkati masalah/materi pada muatan hukum yang hendak dianalisis. Melalui penggunaan konsep ini, setidaknya bisa merancang argumen untuk menjawab materi muatan hukum yang dijadikan kajian.

\section{Teknik Pengumpulan Dan Pengolahan Bahan Hukum}

Teknik dalam mengumpulkan bahan hukum sebagai prosedur peneliti guna mendapatkan bahan hukum. Teknik mengumpulkan bahan hukum sangat bergantung kepada jenis kajiannya. Bahan hukum primer, meliputi pengumpulan undang-undang mempergunakan prosedur inventarisasi maupunpengategorisasi. Bahan hukum sekunder terkumpulkan melalui sistematika kartu catatan.

\section{Analisis Bahan Hukum}

Bahan hukum didapat setelah dihimpun dan disusun, selanjutnya menganalisis, serta diidentifikasi dengan mempergunakan teknik analisis prespkriptif melalui metode sistematisasi. Sehingga dapat ditarik kesimpulan dan memberikan saran sesuai dengan permasalahannya.

\section{Hasil dan Pembahasan}

Pembalikan beban pembuktian adalah sistematika pembuktian yang tidak dikenal apda KUHAP. Di Indonesia, pembuktian terbalik tertuang di Perundang-UndanganNo.25 Tahun 2003 jo Perundang-UndanganNo. 8 Tahun 2010 terkait Pencegahan dan Pemberantasan Tindak Pidana Pencucian Uang, serta Perundang-UndanganNo. 20 Tahun 2001 terkait Pemberantasan Tindak Pidana Korupsi. Terkait pembalikan beban pembuktian yang ada di tindak pidana pencucian uang sesuaiPerundang-UndanganNo. 8 Tahun 2010 terkait tindak pidana pencucian uang (money laundering). Pasal 77 UU TPPU (tindak pidana pencucian uang) memaparkan bila bagi kepentingan pemeriksaan di pengadilan, terdakwa harus memberi bukti jika hartanya bukan hasil dari tindak pidana. Sesuai Pasal 78 Ayat (1) UU TPPU secara inti, hakim memberi perintah bagi terdakwa supaya memberi bukti bila harta yang terkait dengan perkara tidak berasal dari tindak 
pidana sesuai penjelasan di Pasal 2 Ayat (1). Berdasar ketetapan Pasal 35 PerundangUndanganNo.

15 Tahun 2002 jo Perundang-UndanganNo.25 Tahun 2003 mengenai Pencegahan dan Pemberantasan Tindak Pidana Pencucian Uang. Demi kepentingan pemeriksaan di persidangan, terdakwa berkewajiban memberi bukti jika harta yang diperolehnya bukanlah hasil dari tindak pidana.

Pada Pasal 77 Perundang-UndanganNo. 8 Tahun 2010 memperjelas bila demi pemeriksaan di persidangan, terdakwa berkewajiban memberi bukti bila harta yang diperoleh bukanlah hasil dari tindak pidana. Terkait hal itu, dalam Pasal 78 Ayat (1) dijelaskan bila pemeriksaan di persidangan sesuai yang tercantum di Pasal 77, hakim memberikan perintah kepada terdakwa supaya memberi bukti bila harta yang berkaitan dengan perkara tidak berasal dari tindak pidana.

Bagaimana usaha pembuktian terhadap beban pembuktian terbalik? Menurut analisa penulis, jawaban dari pertanyaan tersebut adalah berkaitan dengan bagaimana upaya pembuktian beban pembuktian dalam perkara tindak pidana korupsi maupun sistematika pembalikan pembultian dalam tindak korupsi (Nurfanto, Sari, Harwika, Michael, \& Hadi, 2021). Pada pembuktian terbalik, pihak yang wajib membuktikan ialah terdakwa. Sesudah terdakwa mendapatkan perintah dari hakum di persidangan pengadilan. Walau Perundang-Undangan Nomor 8 Tahun 2010 mengenai Pemberantasan Tindak Pidana Pencucian Uang tidak menjelsakan terkait waktu yang tepat kapan untuk terdakwa membuktikan hartanya, tetapi bila melihat sistematika pengadilan, berarti saat pemeriksaan atau mendengar keterangan terdakwa itulah saat yang tepat untuk melakukan proses pembuktian.

Pembalikan beban pembuktian terkait mengembalikan kerugian keuangan negara ialah penjelasan dari terdakwa pada upaya membuktikan bila harta benda tidak berasal dari tindak korupsi. Kesuksesan terdakwa memberi bukti terkait harta dakwaannya ialah harta yang halal, sebab asal dari penambahan harta kekayaan dari sumber yang halal, sehingga tanpa memengaruhi apa pun pada pembuktian penutut umum terkait perkara pokok, bila penutut umum sukses memberi bukti terkait unsur maupun terbukti terdakwa bersalah melaksanakannya.

Jika terdakwa tidak mampu memberi bukti terkait sumber pendapatan yang berimbang dengan kekayaan atau tanpa terbukti sumber kekayaannya halal, maka penutut umum bisa mempergunakan kondisi sedemikian rupa guna menguatkan alat bukti bila terdakwa bertindak korupsi. Bila terdakwa mampu memberikan bukti atas perimbangan tersebut, maka harta yang didakwakan tanpa ada keterkaitan dengan tindak pidana yang didakwakan, serta harta bendanya tidak terampas (memperoleh sanksi pidana perampasan barang) bagi negara.

\section{Kesimpulan}

Bagaimana upaya pembuktian terhadap beban pembuktian terbalik?. Menurut analisa penulis, jawaban dari pertanyaan tersebut adalah berkaitan dengan bagaimana 
upaya pembuktian beban pembuktian yaitu terdakwa dalam perkara tindak pidana koripsi. serta juga mekanisme/tatacara pembalikan beban pembuktian dalam korupsi. Pada pembuktian terbalik, pihak yang harus membuktikan ialah terdakwa. Sesudah terdakwa mendapatkan perintah dari hakim pada pemeriksaan di persidangan, walau PerundangUndanganNomor 8 Tahun 2010 terkait Pemberantasan Tindak Pidana Pencucian Uang tanpa memperjelas waktu yang tepat untuk terdakwa membuktikan hartanya, tetapi bila melihat sistematika pengadilan, berarti saat pemeriksaan atau mendengar keterangan terdakwa itulah saat yang tepat untuk melakukan proses pembuktian. Keberhasilannya adalah ketika terdakwa memberi bukti terkait harta yang didakwakan ialah harta yang halal, sebab sumber penambahan kekayaan berasal dari sumber yang halal. Bila terdakwa tanpa bisa memberi bukti bila sumber pendapatan yang berimbang dengan kekayaan atau tanpa terbukti sumber kekayaan ialah halal, maka penutut umum bisa mempergunakan kondisi sedemikian rupa guna menguatkan alat bukti bila terdakwa bertindak pidana korupsi. 
Hari Soeskandi, Setia Sekarwati.

\section{Bibliografi}

Barama, Michael. (2012). Pembuktian Terbalik Perkara Pidana Korupsi.

Budiartha, I. (2016). HUKUM OUTSOURCING: Konsep Alih Daya, Bentuk Perlindungan, dan Kepastian Hukum. Setara Press.

Husodo, Adnan Topan, Sunaryanto, Agus, Yuntho, Emerson, Diansyah, Febri, Abid, Lais, \& Langkun, Tama S. (2011). Evaluasi Dan Roadmap Penegakan Hukum Kpk 2012-2015.

Indrayana, Denny. (2011). Indonesia Optimis. Bhuana Ilmu Populer.

Lalo, Kalfaris. (2018). Menciptakan generasi milenial berkarakter dengan Pendidikan karakter guna menyongsong era globalisasi. Jurnal Ilmu Kepolisian, 12(2), 8.

Lamintang, P. A. F. (1997). Dasar-dasar untuk mempelajari Hukum Pidana yang berlaku di Indonesia. Citra Aditya Bakti.

Marzuki, Peter Mahmud. (2011). Penelitian Hukum, Jakarta: Kencana. Mertokusumo, Sudikno.

Mertokusumo, M. Sudikno, \& Pitlo, Adriaan. (1993). Bab-bab tentang penemuan hukum. Citra Aditya Bakti.

Nurfanto, Luki, Sari, Amelia Puspita, Harwika, Dara Manista, Michael, Tomy, \& Hadi, Syofyan. (2021). Kebaruan Dalam Jurnal. Tomy Michael.

Nurhayani, Nurhayani. (2015). Pembuktian Terbalik dalam Pemeriksaan Tindak Pidana Korupsi di Indonesia. Jurnal IUS Kajian Hukum Dan Keadilan, 3(1).

Prasetia, M. Edo Rezawan, Permana, Sandhi, \& Dewi, Yunita Kurnia. (2014). Sistem Pembuktian Terbalik Dalam Pembuktian Perkara Gratifikasi. Verstek, 2(2).

Runturambi, Josias Simon. (2017). Makna Kejahatan dan Perilaku Menyimpang dalam Kebudayaan Indonesia. Antropologi Indonesia, 125-135.

Ryana, Pricilia, \& Idzati, Aisy. (2018). Korupsi Dalam Kajian Hukum Dan Hak Asasi Manusia. Lex Scientia Law Review, 2(2), 177-188.

Supusepa, Reimon. (2019). Problematika Pembuktian Terbalik Dalam Perkara Tindak Pidana Korupsi. JURNAL BELO, 4(2), 134-144. 